\title{
Kemampuan Ekstrak Kulit Buah Kabau (Archidendron microcarpum) dalam Mengendalikan Crocidolomia pavonana (Lepidoptera: Crambidae)
}

\author{
(Ability of Kabau Fruit Crude Extract (Archidendron microcarpum) in Controlling \\ Crocidolomia pavonana (Lepidoptera: Crambidae) \\ Obel $^{1)^{*}}$, Dwinardi Apriyanto ${ }^{2)}$, dan Tunjung Pamekas ${ }^{2)}$ \\ 1) Program Studi Agroteknologi, Fakultas Pertanian, Universitas Andalas \\ 2) Program Studi Agroekoteknologi, Fakultas Pertanian, Universitas Bengkulu \\ E-mail: owbel@agr.unand.ac.id \\ Diterima: 23 Maret 2020 Disetujui: 15 Juni 2020 Dipublikasi: 30 Juni 2020
}

\begin{abstract}
Crocidolomia pavonana Fabricius is an important pest in the Brassicaceae family that can cause up to $10 \%-100 \%$ yield losses. One of the plants that are considered as potential botanical insecticides is Kabau Plant (Archidendron microcarpum (Benth.). This study was aimed to determine the ability of kabau pell crude extract to control C.pavonana. The study was conducted at Rejang Lebong State Community Academy Campus and Natural Resources Organic Laboratory of Faculty of Mathematics and Natural Sciences, Universitas Andalas, from September 2016 to February 2017. The research was conducted in three stages: filter, bioactivity, and chemical profile examination. The results showed that the kabau peel crude extract was classified as an active insecticide for C.pavonana. At a concentration of $0.5 \%$, kabau peel crude extract caused larval mortality to reach $63.33 \%$ in the filter test and $70 \%$ in the bioactivity test. The extract consisted of phenolic compounds, saponins, flavonoids, steroids, terpenoids, and alkaloids.
\end{abstract}

Keywords: Kabau plant, secondary metabolite, botanical insecticide, Crocidolomi pavonana

\section{PENDAHULUAN}

Kehadiran serangga hama menjadi salah satu faktor pembatas dalam budidaya tanaman yang keberadaanya dapat mempengaruhi kualitas dan kuantitas hasil yang diperoleh. Salah satunya adalah ulat krop (Crocidolomia pavonana), hama penting pada tanaman famili Brassicaceae seperti kubis, kubis bunga, petsai dan lobak. Menurut Khalsoven (1981), serangga hama ini, khususnya pada daerah dataran tinggi menyebabkan kehilangan hasil mencapai 10-100\% (Uhan, 1993). Paat et al. (2012) melaporkan tingkat serangan C. pavonana di Tomohon mencapai $37,5 \%$ bahkan sampai $48,83 \%$ (Badjo et al., 2015) sedangkan di daerah Gianyar Bali, tingkat serangan mencapai 60,56\% (Kumarawati et al., 2013). Dengan kondisi seperti itu, keberadaan hama ter-sebut sangat merugikan petani sehingga perlu dilakukan tindakan pengendalian antara lain dengan menggunakan insektisida nabati.

Penggunaan insektisida nabati mempunyai banyak kelebihan dibandingkan dengan insektisida sintetik seperti mudah terurai di alam sehingga tidak mencemari lingkungan dan relatif aman 
bagi manusia. Insektisida nabati dapat diperoleh dengan memanfaatkan hasil metabolisme sekunder berbagai jenis tumbuh-tumbuhan (Priyono, 2006). Hal ini didukung dengan keanekaragaman flora yang berbeda disetiap daerah di Indonesia. Banyak jenis tumbuhan yang berpotensi dan dapat diolah menjadi bahan insektisida nabati. Menurut Isman (2006), beberapa famili tumbuhan yang berpotensi sebagai insektisida nabati yaitu Meliaceae, Annonaceae, Rutaceae, Piperaceae dan Verbenaceae.

Salah satu tumbuhan dari Famili Fabaceae yang diduga berpotensi sebagai insektisida nabati adalah tumbuhan kabau (Archidendron microcarpum). Biasanya, tumbuhan ini hidup di daerah tropis, dan termasuk tumbuhan liar yang tumbuh di hutan-hutan Sumatera. Buah kabau berbau tidak sedap layaknya jengkol dan petai yang banyak digunakan sebagai sayuran. Kulit buah kabau sering menjadi limbah dan sumber polusi di pasar-pasar tradisional. Tumbuhan ini tergolong satu famili dengan jengkol (Pithecollobium lobatum) yang sebelumnya telah dilaporkan efektif dalam mengendalikan Heliothis armigera dan Spodoptera litura dengan tingkat mortalitas mencapai $70 \%$ pada konsentrasi $10 \%$ (Ambarningrum et al., 2009), memperpendek umur tikus 10,67 hari setelah aplikasi dengan pemberian cairan $200 \mathrm{~g}$ biji jengkol/liter air (Pakki et al., 2009), dan siput murbei dengan mortalitas sampai 100\% (Astuti, 2013).

Tanaman dari famili Fabaceae sebagian besar dimanfaatkan sebagai obat karena mengandung metabolit sekunder seperti alkaloid, glikosida, flavanoid, terpenoid, lignin, minyak atsiri, antosianin, gossipol, diosgenin (Solikin, 2009). Belum diperoleh hasil penelitian tentang kandungan senyawa metabolit sekunder yang dimiliki oleh kulit buah kabau, akan tetapi Pitojo (1995) menemukan senyawa terpenoid, saponin, asam fenolat serta alkaloid pada jengkol. Senyawa tersebut sudah banyak dimanfaatkan sebagai insektisida nabati. Berdasarkan kekerabatan tersebut, maka dilakukan penelitian dengan tujuan untuk mengetahui kemampuan ekstrak kulit buah kabau dalam mengendalikan Crocidolomia pavonana.

\section{METODOLOG}

Penelitian ini telah dilaksanakan di Kampus Akademi Komunitas Negeri Rejang Lebong, Kabupaten Rejang Lebong dan Laboratorium Organik Bahan Alam Fakultas MIPA Universitas Andalas, Padang.

\section{Metode}

Penelitian ini dilakukan dalam tiga tahap yaitu uji tapis, uji bioaktivitas, uji penghambatan makan, dan pemeriksaan fitokimia. Rancangan yang digunakan pada uji tapis adalah Rancangan Acak Lengkap (RAL) faktorial 2 faktor $(2 \times 3)$. Faktor I adalah jenis ekstrak (ektrak kulit buah dan ekstrak biji kabau). Faktor II adalah konsentrasi ekstrak $(0 \%, 0,1 \%, 0,5 \%)$. Tiap kombinasi perlakuan dilakukan dalam 3 kali ulangan. Pelaksanaannya mengikuti metode Arneti (2012). Tiap ulangan terdiri dari 10 larva instar 3.

Ekstrak yang lebih aktif pada uji tapis diuji lebih lanjut pada uji bioaktivitas ekstrak dengan metode residu pada daun. Rancangan percobaan yang digunakan pada tahap ini adalah Rancangan Acak Lengkap (RAL) dengan enam perlakuan dan tiga ulangan. Perlakuan berupa perbedaan konsentrasi ekstrak ( $0 \%, 0,1 \%, 0,2 \%, 0,3 \%$, $0,4 \%$ dan $0,5 \%)$. Tiap ulangan terdiri dari 10 larva instar 3.

Uji penghambatan makan dilakukan dengan metode residu pada daun dengan uji pilihan makan. Rancangan percobaan yang digunakan adalah Rancangan Acak Lengkap (RAL) dengan enam perlakuan dan tiga ulangan. Perlakuan berupa perbedaan konsentrasi ekstrak $(0 \%, 0,1 \%$, $0,2 \%, 0,3 \%, 0,4 \%$ dan $0,5 \%)$. Tiap ulangan terdiri dari 10 larva instar 3. 
Pemeriksaan profil kimia dilakukan untuk mengetahui kandungan fraksi kasar senyawa metabolit sekunder pada kulit buah dan biji kabau yang dilakukan dengan mengikuti metode yang dilakukan oleh Manjang (2002) di laboratorium organik bahan alam Fakultas MIPA Universitas Andalas, Padang. Sampel segar sebanyak 2 $\mathrm{g}$ dipotong kecil dan dimasukkan ke dalam tabung reaksi. Sampel dimaserasi dengan etanol yang sudah dipanaskan selama 15 menit kemudian disaring hingga etanol menguap dan kering. Setelah sampel kering ditambahkan kloroform dan air suling 1:1 masing-masing sebanyak $5 \mathrm{ml}$ kemudian dikocok dan dipindahkan ke tabung reaksi lainnya dan dibiarkan hingga terlihat dua lapisan yaitu lapisan air dan lapisan kloroform yang akan digunakan untuk pemeriksaan metabolit sekunder.

\section{Pembuatan ekstrak kulit dan biji kabau}

Kulit buah dan biji kabau diperoleh dari pedagang sayur Pasar Atas Curup Kabupaten Rejang Lebong, Bengkulu. Sampel tersebut dikering-anginkan, dipotong, kemudian digiling dengan blender sampai halus. Setiap bahan kemudian ditimbang sebanyak $100 \mathrm{~g}$ lalu dimasukkan ke dalam gelas kaca ukuran 1 liter dan direndam dengan etanol sebanyak $500 \mathrm{ml}$ kemudian ditutup rapat. Larutan ekstrak dibiarkan selama 24 jam lalu diaduk dengan pengaduk kaca selama 15 menit. Ekstrak tersebut disaring dengan corong gelas yang dialasi kertas saring, kemudian diuapkan dengan rotary evaporator pada suhu $50^{\circ} \mathrm{C}$ dengan tekanan rendah (400$500 \mathrm{~mm} \mathrm{Hg}$ ). Ekstrak yang diperoleh, dimasukkan ke dalam botol berwarna gelap dan disimpan dalam lemari pendingin dengan suhu $4^{\circ} \mathrm{C}$ sampai saat digunakan untuk perlakuan.

\section{Penyediaan pakan serangga uji}

Daun kubis yang dijadikan sebagai bahan pakan serangga uji diperoleh dari tanaman kubis yang ditanam sendiri di rumah plastik Kampus Akademi Komunitas Negeri Rejang Lebong. Budidaya dilakukan sesuai kebiasaan petani tapi tanpa aplikasi pestisida.

\section{Perbanyakan C. pavonana}

Larva yang dikoleksi adalah larva instar awal yang berasal dari pertanaman kubis di Desa Sumber Urip, Kabupaten Rejang Lebong, Bengkulu. Larva tersebut dipelihara sampai instar 3 dengan ciri berwarna hijau dengan panjang 1,1-1,3 $\mathrm{cm}$.

\section{Pengujian dan pengamatan Uji tapis}

Sebanyak 180 ekor larva C. pavonana instar 3 disiapkan untuk uji penapisan ini, masing-masing 10 ekor untuk setiap ulang-an. Larutan ekstrak yang telah diencerkan dengan aquades disiapkan dalam cawan petri sesuai perlakuan. Daun kubis dipo-tong dengan ukuran $5 \mathrm{~cm} \times 5 \mathrm{~cm}$ lalu dicelupkan satu persatu ke dalam larutan tersebut sampai basah merata kemudian dikering-anginkan, untuk selanjutnya ditempatkan di cawan petri lain. Sebanyak 10 ekor larva instar 3 diinfestasikan dan dibiarkan makan daun tersebut. Setelah 48 jam, dilakukan penghitungan terhadap jumlah larva yang mati. Semua larva yang mati dikeluarkan dari cawan petri, sedangkan larva yang masih hidup dipelihara dan diberi makan dengan daun kubis segar bebas pestisida tanpa perlakuan.

\section{Uji bioaktivitas ekstrak}

Prosedur pelaksanaan uji bioaktivitas ekstrak sama dengan prosedur pelaksanaan uji tapis. Hanya saja pengamatan larva yang mati dilakukan mulai pada hari pertama, larva yang masih hidup dipelihara dan diberi makan dengan daun kubis segar bebas pestisida tanpa perlakuan. Jumlah larva yang mati dan yang bertahan hidup terus diamati sampai hari ke 7 setelah perlakuan. Pengujian ini menggunakan metode residu pada daun. 
Obel et al. Kemampuan Ekstrak Kulit Buah Kabau

Sebanyak 180 ekor larva C. pavonana instar 3 disiapkan untuk uji bioaktivitas ekstrak ini. Larutan ekstrak yang telah diencerkan dengan aquades sesuai perlakuan disiapkan dalam cawan petri. Daun kubis dipotong dengan ukuran $5 \mathrm{~cm} \times 5 \mathrm{~cm}$ lalu dicelupkan satu persatu ke dalam larutan tersebut sampai basah merata. Sebanyak 10 ekor larva instar 3 diinfestasikan dan dibiarkan makan pada setiap perlakuan. Setelah 48 jam, dilakukan penghitungan terhadap jumlah larva yang mati. Semua larva yang mati dikeluarkan dari cawan petri, sedangkan larva yang masih hidup dipelihara dan diberi makan dengan daun kubis segar bebas pestisida tanpa perlakuan. Jumlah larva yang mati dan yang bertahan hidup terus diamati sampai hari ke 7 setelah perlakuan.

\section{Uji penghambatan makan}

Pengujian dilakukan dengan metode residu pada daun dengan uji pilihan makan. Sebanyak 2 helai daun perlakuan dan 2 helai daun tanpa perlakuan berukuran $5 \mathrm{~cm} \times 5 \mathrm{~cm}$ dimasukkan ke dalam cawan petri. Kemudian 10 ekor larva instar 3 diinfestasikan ke dalam cawan petri lalu dibiarkan selama 24 jam.

\section{Parameter pengamatan Mortalitas larva}

Hasil pengamatan mortalitas larva pada uji tapis dilakukan pada hari ke 2 setelah perlakuan yang ditampilkan dalam bentuk tabel sedangkan pada uji bioaktivitas dilakukan mulai pada hari pertama sampai hari ke tujuh setelah perlakuan yang ditampilkan dalam bentuk gambar. Mortalitas larva C.pavonana diperoleh dengan menggunakan rumus:

Po $=\frac{\mathrm{a}}{\mathrm{b}} \times 100 \%$

Keterangan :

Po $=$ Mortalitas larva

$a=$ Jumlah larva yang mati

$\mathrm{b}=$ Jumlah larva yang disediakan

\section{Luas daun yang dimakan}

Data ini diperoleh dari uji penghambatan makan. Luas daun yang dimakan oleh larva C.pavonana, baik dengan perlakuan dan tanpa perlakuan diukur dengan cara meletakkan diatas kertas millimeter dan menggambarkannya.

\section{Pengolahan dan analisis data}

Mortalitas larva hasil pengamatan pada uji bioaktivitas dianalisis dengan sidik ragam dan bila berbeda nyata dilanjutkan dengan uji kontras ortogonal. Data tentang penghambatan aktivitas makan dianalisis dengan sidik ragam dan bila berbeda nyata dilanjutkan dengan uji Parametrik.

\section{HASIL}

\section{Uji tapis}

Pengujian ekstrak kulit buah dan biji kabau terhadap larva C. pavonana instar 3 menunjukkan bahwa kedua jenis ekstrak tersebut dapat menyebabkan kematian pada serangga uji dari $6,67 \%-63,33 \%$. Hal ini menunjukkan bahwa kedua bagian buah kabau ini cukup aktif jika digunakan sebagai insektisida nabati, akan tetapi kulit buah lebih aktif dibandingkan bijinya (Tabel 1).

Tabel 1. Mortalitas larva C. pavonana instar 3 setelah diberi perlakuan ekstrak kulit buah dan biji kabau (2 hari setelah perlakuan)

\begin{tabular}{lcc}
\hline Jenis ekstrak & Konsentrasi (\%) & Mortalitas Larva (\%) \\
\hline Biji kabau & 0 & 0,00 \\
& 0,1 & 6,67 \\
& 0,5 & 43,33 \\
\hline Kulit buah kabau & 0 & 0,00 \\
& 0,1 & 13,33 \\
& 0,5 & 63,33 \\
\hline
\end{tabular}


Obel et al. Kemampuan Ekstrak Kulit Buah Kabau

\section{Uji bioaktivitas}

Berdasarkan uji bioaktivitas diketahui bahwa perbedaan konsentrasi kulit buah kabau telah menyebabkan kematian larva C.pavonana instar 3, dengan mortalitas terendah adalah $10 \%$ pada konsentrasi $0,1 \%$ dan tertinggi $70 \%$ pada konsentrasi $0,5 \%$. Semakin tinggi konsen- trasi yang diberikan, semakin tinggi pula mortalitas larva. Hasil uji kontras ortogonal menunjukkan bahwa peningkatan konsentrasi berpengaruh sangat nyata secara linear $(P=0,0000)$ terhadap mortalitas larva, yang disederhanakan dalam bentuk persamaan $y=0,317+14,38 x$ (Gambar 1 ).

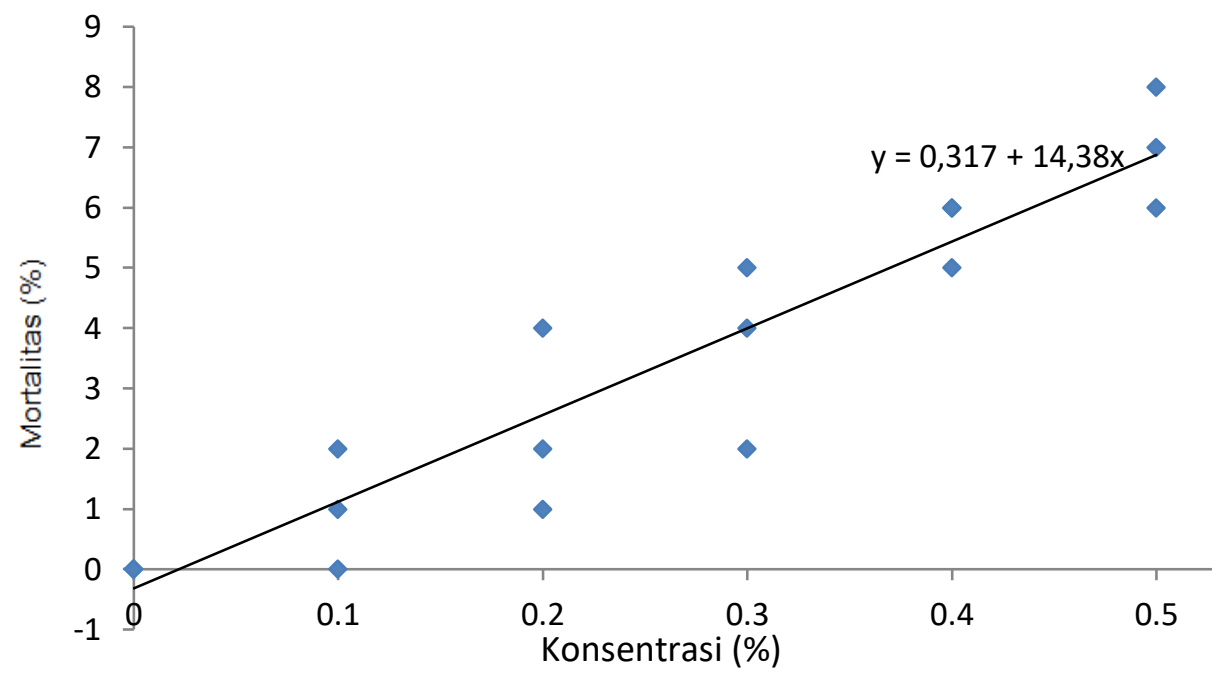

Gambar 1. Mortalitas larva C. pavonana setelah diperlakukan dengan ekstrak buah kabau dengan konsentrasi berbeda pada 7 hari setelah perlakuan

Pada hari pertama setelah perlakuan, belum ada satupun larva C.pavonana yang mati. Mortalitas larva baru terjadi pada hari kedua setelah perlakuan dengan kisaran $10-70 \%$. Mortalitas tersebut terus meningkat sampai hari ke tujuh yang mencapai $83,33 \%$. Mortalitas tertinggi terjadi pada konsentrasi $0.5 \%$, dan yang terendah terjadi pada konsentrasi 0,1\% (Gambar 2).

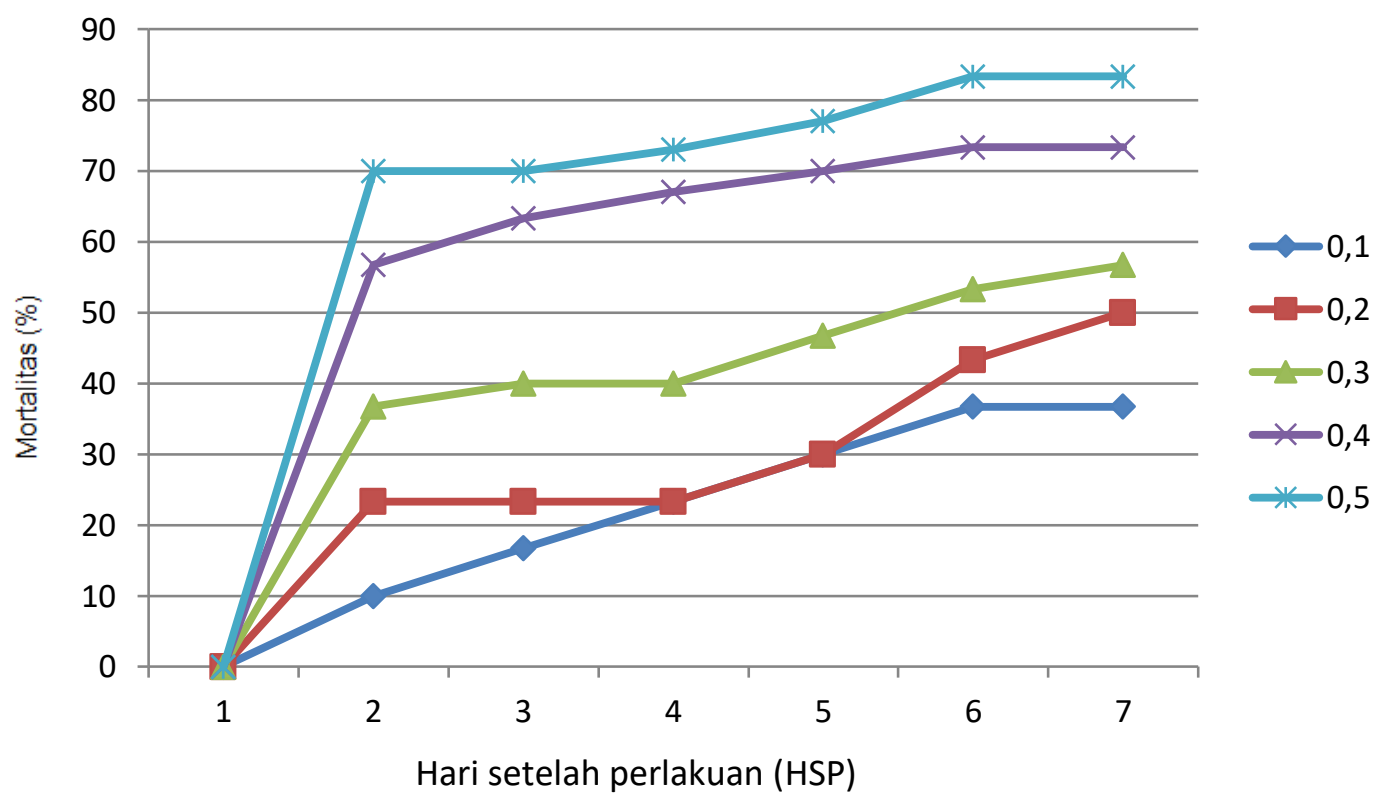

Gambar 2. Mortalitas larva C. pavonana setelah diperlakukan dengan ekstrak buah kabau dengan konsentrasi berbeda selama 7 hari pengamatan 


\section{Uji aktivitas penghambatan makan}

Ekstrak kulit buah kabau dapat menghambat aktivitas makan dari larva C.pavonana. Luas daun kubis perlakuan yang dimakan lebih sedikit dibandingkan luas daun kubis tanpa perlakuan. Peningkatan konsentrasi ekstrak kulit buah kabau telah menghambat jumlah daun yang dimakan. Berdasarkan uji parametrik, peningkatan konsentrasi berpengaruh nyata terhadap rata-rata luas daun yang dimakan serangga uji (T-test:T=-6.95, $\mathrm{P}<0.001$ ) seperti pada Tabel 2 .

Tabel 2. Rata-rata luas daun kubis yang dimakan larva C. pavonana instar 3 yang diperlakukan dengan konsentrasi ekstrak kulit buah kabau yang berbeda

\begin{tabular}{cccccc}
\hline $\begin{array}{c}\text { Konsentrasi } \\
(\%)\end{array}$ & $\mathrm{N}$ & $\begin{array}{c}\text { Luas daun perlakuan } \\
\text { yang dimakan }\left(\mathrm{cm}^{2}\right)\end{array}$ & $\begin{array}{c}\text { Luas daun tanpa perlakuan } \\
\text { yang dimakan }\left(\mathrm{cm}^{2}\right)\end{array}$ & $\mathrm{t}$ & $\mathrm{P}$ \\
\hline 0,1 & 3 & 18,71 & 24,83 & $-38,28$ & 0,0007 \\
0,2 & 3 & 17,01 & 23,71 & $-9,23$ & 0,0115 \\
0,3 & 3 & 13,35 & 24,03 & $-5,77$ & 0,0287 \\
0,4 & 3 & 11,84 & 21,93 & $-8,70$ & 0,0130 \\
0,5 & 3 & 8,67 & 24,52 & $-42,05$ & 0,0006 \\
\hline Rata-rata & 15,66 & 23,98 & $-6,95$ & 0,0000 \\
\hline
\end{tabular}

\section{Pemeriksaan profil fitokimia}

Berdasarkan pemeriksaan profil fitokimia pada kulit buah dan biji kabau diketahui bahwa pada kedua bahan samasama ditemukan senyawa metabolit sekunder berupa fenolik, saponin, flavonoid, steroid, terpenoid dan alkaloid. Pengamatan ini hanya untuk mengetahui ada atau tidak adanya kandungan dari masingmasing metabolit sekunder.

\section{PEMBAHASAN}

Ekstrak kulit buah kabau lebih aktif dibandingkan ekstrak bijinya dengan aktivitas mencapai 63,33\% (Tabel 1). Prijono (2003) menyatakan bahwa ekstrak uji dinyatakan aktif dan bisa digunakan sebagai insektisida nabati apabila penggunaan konsentrasi $0,5 \%$ dapat mematikan serangga uji diatas 50\%. Sementara itu, Arneti (2012) menyatakan bahwa suatu ekstrak dikatakan tidak aktif karena kandungan senyawanya kurang aktif ataupun senyawanya cukup aktif tetapi terdapat pada konsentrasi yang rendah sehingga menyebabkan tingkat mortalitas serangga menjadi rendah pula.
Semakin tinggi konsentrasi ekstrak kulit buah kabau yang diberikan, semakin tinggi pula mortalitas larva $C$. pavonana. Mortalitas tertinggi terjadi pada konsentrasi $0,5 \%$ yakni mencapai $70 \%$ pada hari kedua dan mencapai 83,33\% pada hari ke tujuh setelah perlakuan (Gambar 1, Gambar 2). Ekstrak kulit buah kabau dengan konsentrasi $0,5 \%$ dapat menghambat aktivitas makan dari larva C.pavonana jauh melebihi daun kontrol.

Mortalitas larva yang tidak mencapai $100 \%$ kemungkinan dipengaruhi oleh keadaan larva itu sendiri. Larva yang digunakan berasal dari pertanaman kubis Desa Sumber Urip Kabupaten Rejang Lebong. Berdasarkan hasil wawancara langsung dengan petani setempat (Susanto, 2017, komunikasi pribadi), rata-rata petani secara turun temurun melakukan aplikasi pestisida sekali tiga hari meskipun tingkat serangan masih sedikit sehingga diduga larva uji sudah resisten terhadap insektisida. Menurut Georghiou dan Mellon (1983), tinggi rendahnya tingkat resistensi hama dipengaruhi oleh perilaku petani dalam menggunakan insektisida untuk mengendalikan hama kubis, baik frekuensi 
penyemprotan maupun pola penggunaan insektisida.

Kandungan senyawa metabolit sekunder yang terdapat dalam ekstrak kulit kabau berperan penting sebagai penyebab tinggi rendahnya mortalitas larva $C$. pavonana. Berdasarkan pemeriksaan profil fitokimia, kulit buah dan biji kabau mengandung metabolit sekunder berupa fenolik, saponin, flavonoid, steroid, terpenoid dan alkaloid. Senyawa tersebut dikenal sebagai sumber insektisida nabati. Menurut Harborne (1988), alkaloid, terpenoid, flavonoid, dan tannin mempunyai aktivitas menghambat makan serangga. Sifat toksik alkaloid terutama mengganggu system syaraf. Senyawa terpenoid mempunyai aktivitas sebagai racun syaraf, penghambat makan, dan penghambat oviposisi, sedangkan aktivitas dari saponin yang merupakan kelompok triterpenoid adalah menurunkan enzim protease dalam saluran makanan serangga serta mengganggu penyerapan makanan. Aktivitas saponin yang lain adalah mengikat sterol bebas dalam saluran pencernaan makanan (Gershenzon dan Croteau, 1991).

Senyawa metabolit sekunder berfungsi sebagai pertahanan tanaman terhadap serangan serangga. Pengaruhnya dapat terjadi baik secara langsung dengan cara membunuh serangga hama dalam waktu singkat maupun secara tidak langsung dengan membunuh secara perlahan-lahan seperti penghambatan makan pada serangga. Menurut Isman (2006), senyawa kimia yang dihasilkan oleh tumbuhan dapat mempengaruhi berbagai aktivitas serangga yang memakannya seperti penghambat makan, penghambat peletakan telur oleh imago serangga dan mengganggu proses perkembangan serangga.

\section{KESIMPULAN}

Ekstrak kulit buah kabau tergolong aktif untuk digunakan sebagai insektisida nabati C. pavonana. Pada konsentrasi $0,5 \%$, eks- trak tersebut menyebabkan mortalitas larva mencapai $63,33 \%$ pada uji tapis dan 70\% pada uji bioaktivitas. Ekstrak kulit buah kabau juga mampu menghambat makan larva karena pada konsentrasi 0,5\% mengonsumsi daun kubis jauh lebih rendah dari kontrol. Kandungan metabolit sekunder ekstrak ini berupa senyawa fenolik, saponin, flavonoid, steroid, terpenoid dan alkaloid.

\section{DAFTAR PUSTAKA}

Ambarningrum TB, Arthadi, H Pratiknyo, S Priyanto. 2008. Ekstrak kulit jengkol (Pithecellobium lobatum): Pengaruh sebagai anti makan dan terhadap efisiensi pemanfaatn makanan instar $\checkmark$ Heliothis armigera. Sains MIPA 13: $165-170$.

Arneti. 2012. Bioaktivitas ekstrak buah Piper aduncum L. (Piperaceae) terhadap Crocidolomia pavonana (F.) (Lepidoptera : Crambidae) dan formulasinya sebagai insektisida nabati. [Disertasi]. Universitas Andalas. Padang.

Astuti P. 2013. Uji efektifitas kulit buah jengkol (Pithecolobium lobatum) terhadap kematian siput murbei (Pomacea canaliculata). Ziraa'ah 37: $40-45$.

Georghiou GP dan RB Mellon. 1983. Pesticide resistance in time and space. dalam: Georghiou GP dan T Saitoeditor. Pest resistance to pesticide. Plenum Press. New York.

Isman MB. 2006. Botanical insecticides, deterrent, and repellents in modern agriculture and an increasingly regulated world. Annual reviews of Entomology 51: $45-66$.

Manjang Y. 2002. Penelitian kimia organik bahan alam. Pelestarian, pengembangan melalui taman agrowisata dalam Workshop Peningkatan Sumberdaya Manusia Kajian Kimia Orga- 
Obel et al. Kemampuan Ekstrak Kulit Buah Kabau

nic Bahan Alam Hayati dan Pelestarian Hutan. 21 - 27 Juli. Padang.

Pakki T, M Taufik dan AM Adnan. 2009. Studi potensi rodentisida nabati biji jengkol untuk mengendalikan hama tikus pada tanaman jagung. Prosiding seminar nasional serealia. Pusat penelitian dan pengembangan produktivitas hutan. Universitas Haluoleo. Sulawesi Tenggara.

Pitojo S. 1995. Jengkol budidaya dan pemanfaatannya. Kanisius. Yogyakarta.

Prijono D. 2003. Teknik ekstraksi, uji hayati, dan aplikasi senyawa bioaktif tumbuhan. Panduan bagi Pelaksana PHT Perkebunan Rakyat. Departemen Hama dan Penyakit Tumbuhan IPB. Bogor.

Uhan TS. 1993. Kehilangan hasil panen kubis karena ulat krop kubis (Crocidolomia binotalis Zell) dan cara pengendaliannya. Hortikultura 3:2226.

Solikin. 2009. Potensi jenis-jenis herba liar di kebun Raya Purwodadi sebagai obat dalam Setiawan, Rahayu $S$, Rumhayati B, Alghofari AR, Naba A, Maryanto $S$, Widodo, Editor.
Proceeding Basic Science National Seminar, Malang.

Harborne JB. 1988. Introduction to ecological biochemistry. 3th edition. Academic Press. London

Gershenzon J dan R Croteau. 1991. Terpenoid dalam herbivores: Their Interaction with secondary plant metabolites. 2nd edition. Eds. GA Rosenthal and MR Barenbaum. Academic Press. New York.

Badjo R, CS Rante, ERM Meray dan BW Assa. 2015. Serangan hama ulat krop (Crocidolomia pavonana) pada tanaman kubis (Brasicca Oleraceae var. Capitata L) di kelurahan Kakaskasen II kec. Timohon Utara kota Tomohon. Cococ 6 (14).

Paat FJ, J Palealu dan J Manueke. 2012. Produksi kubis dan persentase serangan Crocidolomia pavonana pada beberapa pola tanam kubis. Eugenia 18 (1): 72-82.

Kumarawati NPN, IW Supartha dan KA Yuliadhi. 2013. Struktur komunitas dan serangan hama penting tanaman kubis (Brassica oleraceae L). Jurnal Agroekoteknologi Tropika 2 (4): 252259. 